\title{
Ethnopharmacological and toxicological review of Cydonia oblonga M.
}

\author{
Katerina Cvetkovska, Biljana Bauer \\ Faculty of Pharmacy, Ss. Cyril and Methodius University, Majka Tereza 47, \\ 1000 Skopje, Republic of Macedonia
}

Received: October 2018; Accepted: December 2018

\begin{abstract}
Cydonia oblonga M. is a medicinal plant of family Rosaceae which is used to prevent or treat several ailments such as cancer, diabetes, hepatitis, ulcer, respiratory, and urinary infections, etc. Cydonia oblonga commonly known as quince is rich in useful secondary metabolites such as phenolics, steroids, flavonoids, terpenoids, tannins, organic acids, and glycosides. It shows a wide range of pharmacological effects like antioxidant, antibacterial, antifungal, anti-inflammatory, hepatoprotective, cardiovascular, antidepressant, hypolipidemic, diuretic, etc. The polysaccharide mucus, glucuronoxylane located in the seeds of the quince, is used in the dermatology, for the production of wound patches.

The aim of this paper focuses on detailed research on the value of phytochemicals, as pharmacological and attributes of phytomedicine herbs.
\end{abstract}

Keywords: Cydonia oblonga, phytomedicine, pharmacological attributes, folk medicinal uses, quince

\section{Introduction}

Plants are not just a dietary source for human beings and animals. Traditionally, phyto-preparations are used to treat various diseases in Chinese and Ayurvedic systems of therapies (Gilani and Rahman, 2005; Muhammad et al., 2014). This potential of the treatment plants can be supported by numerous scientific evidence (Anwar et al., 2016; Banerjee et al., 2011; Gilani, 1998; Lattanzio et al., 2009; Russell and Duthie, 2011). In response to emerging healthcare challenges, researchers focus on plants to isolate active phytochemicals (Banerjee et al., 2011; Lattanzio et al., 2009; Muhammad et al., 2016; Russell and Duthie, 2011). The relevance of phyto-preparations for the treatment of various disorders is greater in the current era than never before. In traditional Indian folk remedies, more than 25,000 herbal medicinal formulations have been documented (Kusari et al., 2014).

Cydonia oblonga (Syn: Quince, Bahee Dana, Strythion and Safarjal), a herb of the Rosaceae family (Khoubnasabjafari and Jouyban, 2011; Marwat et al., 2009; Torkelson, 1995) is popular for its medical, nutritional and decorative use. Its fruit is used in the food industry (Usmanghani et al., 1997) as a source of pectin that protects colonic damage in irritable bowel syndrome (IBD) and peptic ulcer (Hamauzu et al., 2008; Minaiyan et al., 2012). Also, the presence of vitamin $C$ and various minerals such as phosphorus, calcium, potassium, sodium and nitrogen in the fetus was reported (Rop et al., 2011). Seeds of the plant are traditionally utilized for treating diarrhea, cough, dysentery, throat inflammation, constipation and bronchitis (Duke et al., 2002; Nadkarni, 1976; Prajapati et al., 2006).

\footnotetext{
* biba@ff.ukim.edu.mk
} 
The seed contains sterols, triterpenes and tannins as active phytochemicals, which are responsible for antidiarrheal activity (Ammar et al., 2009; Budriesi et al., 2010; Kirimer et al., 1997). The presence of various phenols, organic acids and amino acids is also present in the seeds of quince (Silva et al., 2005). Leaf extract is effective against diabetes, cancer and haemolysis (Aslan et al., 2010; Carvalho et al., 2010; Costa et al., 2009; Jouyban et al., 2011). The plant also contains an enzyme, a phenol peroxidase which decolorizes carcinogenic aromatic dyes in industrial wastewater (Arabaci and Usluoglu, 2014; Nandi et al., 2009). Essential oils, phenolic compounds, organic acids, tetracyclic sesquiterpens, and ionic glycosides are present in various parts of the quince (De Tommasi et al., 1996; Erdogan et al., 2012; Lutz-Roder et al., 2002; Oliveira et al., et al., 2010).

The wide spread medicinal uses of quince and its valuable phytochemical makeup have attracted our attention to pile up a comprehensive review on its potential bioactive components, bio-medical, and nutritional applications. So far, no comprehensive review has been compiled to describe pharmacological attributes, folk medicinal uses, and phytochemical constituents of quince in recent years in order to bridge the knowledge gap among researchers.

\section{Taxonomy and distribution}

Quince (Family: Rosaceae) is a small tree or bush with a height of 5-8 and 4-5 meters wide. It is the only member of the genus Cydonia. Its fruit has a light yellow color, acquiring a length of 7-12 cm and a width of 6-9 $\mathrm{cm}$. The fruit has an astringent flavor, a characteristic aroma and a number of planar-convex seeds arranged in two vertical rows. The flowers in the spring are light pink with diameter of $5 \mathrm{~cm}$ (Gholgholab, 1961). The leaves are elliptical in shape, 6-11 cm long and have white hairs on the surface. It is native to Iran and Turkey, and is cultivated in India, South Africa, the Middle East, and Europe (Evans et al., 2002; Yildirim et al., 2001). On the basis of the shape of the fruit, two variants of quince are available (Cydonia oblonga sub sp. Maliformis and Polyformis). The fruits of the first one are of apples shaped, while the second type is a pear. The apple-shaped fruit has a larger mass with a subtle, flavor-like taste compared to that of a pear. From the point of view of toxicology, quince is considered safe in terms of toxic effects, but may be manifested by its seeds only when they are ingested in large quantities due to the presence of nitrile components (Huxley et al., 1999). Her fruit is a source of natural phenolic compounds that possess antibacterial, antioxidant, and anti-ulcerative potential (Fattouch et al., 2007; Hamauzu et al., 2008; Wang et al., 2006).

\section{Phytochemistry}

\section{Quince fruit and peel}

Quince fruit has been extensively consumed as a dietary source. Its fruit is used to prepare jams and jellies (Usmanghani et al., 1997). It is also considered an economic and natural source of phenolic compounds (Oliveira et al., 2007; Silva et al., 2004a).

The fruit of quince contains malic acid $(1.2 \pm 0.8 \%)$, sugars $(5.0 \pm 1.0 \%)$, tannins $(0.8 \pm 0.02 \%)$, vitamin $\mathrm{C}$ $(16.8 \pm 0.8 \mathrm{mg} / 100 \mathrm{~g})$, pectin $(1.8 \pm 0.1 \%)$ and minerals such as potassium $(248 \pm 0.02 \mathrm{mg} / 100 \mathrm{~g})$, sodium $(8.0 \pm 0.03$ $\mathrm{mg} / 100 \mathrm{~g})$ calcium $(18.00 .02 \mathrm{mg} / 100 \mathrm{~g})$ and phosphorus (26.0 $\pm 0.04 \mathrm{mg} / 100 \mathrm{~g}$ ), (Rop et al., 2011; Sharma et al., 2011). The importance of fruits and vegetables to reduce the risk of heart disease, aging and cancer is well-known (Fattouch et al., 2007).

These health benefits are attributable to the strong antioxidant potential of phenolic acids and flavonoids present in plants (Silva et al., 2004b)

Given the medical importance of antioxidants, various studies were conducted to determine the phenolic profile and antioxidant potential of quince fruit. Silva et al. (2002a) discovered that fruit contains well-known antioxidants like caffeylic acid $(79.6 \mathrm{mg} / \mathrm{kg})$ and routine $(5.5 \mathrm{mg} / \mathrm{kg})$, while the bark is also a rich source of caffeylic acid $(291 \mathrm{mg} / \mathrm{kg})$ together with other important flavonoids such as caempferol -3-glycoside $(92.9 \mathrm{mg} / \mathrm{g})$, quercetin 3-galactoside $(100.8 \mathrm{mg} / \mathrm{g})$ and caempferol-3ritinoside $(61.1 \mathrm{mg} / \mathrm{g})$ (Fig. 1).

The presence of ascorbic, citric, apple D-(-)-quinic, fumaric and L-shichicic acid was also confirmed in both peel pulp (Silva et al., 2002a).

In another study, HPLC revealed rhamnose, mannose, D-glucose, L-arabinose, and galactose monosaccharides in fruit (Hopur et al., 2011). Furthermore, polysaccharides of quince fruit inhibited activity of tyrosine phosphatase $\left(\mathrm{IC}_{50}=2.07 \mu \mathrm{g} / \mathrm{mL}\right.$ ) indicating its capability to treat type 2 diabetes and obesity (Yildirim et al., 2001). Moreover, nectar of three quince cultivars (Vranjska, Triumph, and Leskovacka) was investigated for contents of D-glucose, fructose, sucrose, maltose, rhamnose, isomaltose, L-arabinose, ribose, D-melezitose, D-panose, D-raffinose, D-trehalose, and sugar alcohols like D-sorbitol, D-mannitol, and Dgalactitol using high performance anion exchange chromatography (HPAEC). The results showed that frost in late spring season affected carbohydrate metabolism thus enhancing concentrations of D-trehalose, fructose, ribose, rhamnose, D-raffinose, D-galactitol, and Dmannitol (Fig. 2). The study inferred stress induced changes in carbohydrate contents as a mechanism to cope with frost stress (Aksic et al., 2015). The phenolic contents of oven and sun dried peels of quince were $36.72 \pm 3.57,10.39 \pm 1.04 \mathrm{mg} / \mathrm{g}$. 


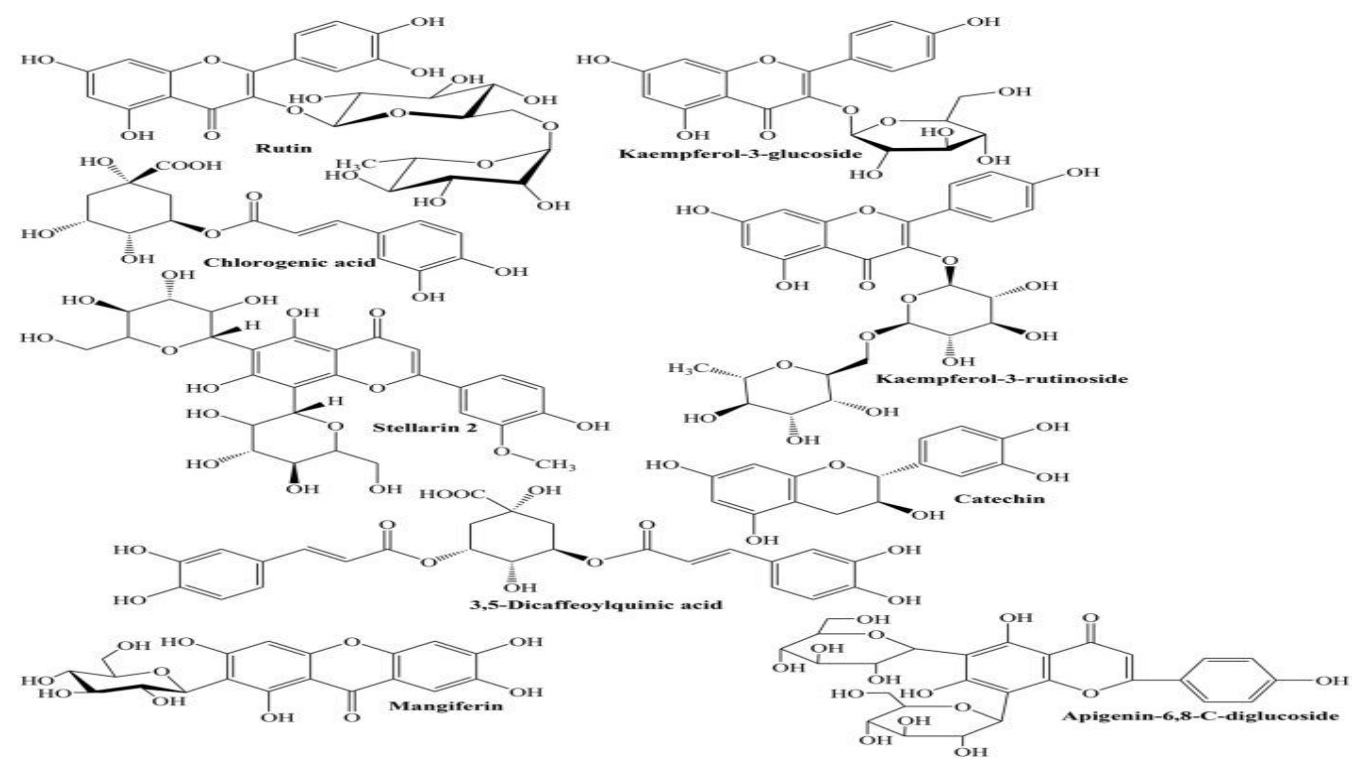

Fig. 1. Some selected polyphenolics isolated from various parts of quince.

The radical scavenging activity of sample $(0.5 \mathrm{mg})$ of cookies, sun dried fruits $(87.0,23.20 \%)$ and peels $(83.35$, $28.91 \%$ ), respectively, clearly suggested that nutritive values of peel and fruit are better preserved in oven drying (Gheisari and Abhari, 2014).

Fattouch et al. (2007) concluded that the total phenolic content (TPC) ranged from 105 to 157 and 37 to $47 \mathrm{mg} / \mathrm{g}$ in bark and pulp, respectively. Chlorogenic acid (5-O-caffeoylquinic acid, $37 \%)$ and routin $(36 \%)$ are major phenolics. In a similar study, Magalhaes et al. (2009) assessed the phenolic profile of the fruit (bark, pulp and seeds) and showed that 5-O-caffeoylquinic acid is the main phenol, while seeds are rich in 6,8-di-Cglycosyl chrysoeriol (stellarin-2) TPC were found to be 6.3, 2.5 and $0.4 \mathrm{~g} / \mathrm{kg}$ for peel, pulp and seeds, respectively. This study supported the fact that the fruit of quince is most often consumed in processed form, that is, jams and jellies, instead fresh form. Silva et al. (2004b) studied the contents of the phenolic, organic and amino acid residues before and after processing the jam.

The peeled and unisolated fruit jams were also analyzed for their phenolic content. The study found that the unpeeled jam contained of a larger percentage of flavonoids $(19 \%)$ of the peeled (3\%). After the processing, concentrations of total phenols of jam were found at $57 \%$ instead of the actual quantity of porridge $(50 \%)$. This might be due to the evaporation of the heat treatment. A change in the 5-O-caffeoylquinic acid was also observed, which may be due to the isomerization caused by the heat treatment. Both the pulp and the bark contain citric, ascorbic, malic, L-shiimic and fumaric acids (Fig. 3). The amino acid profile of the root and pulp was also similar, and it contains 21 amino acids. Laspartic acid, L-glutamic acid, L-cysteine, hydroxyproline and L-serine represent $75-85 \%$ of the total amino acids. The treatment resulted in reduction of concentrations of L-tryptophan, L-histidine and L-glutamic acid due to their thermal degradation (Silva et al., 2004b,c).

Szychowski et al. (2014) showed that both lipophilic and hydrophilic extracts from the quince bark have higher phenolic contents with greater antioxidant activity. The ratio of TPC from root from quince to pulp (TPC peel/TPC pulp) is about 4.7 , where linoleic acid (54.7\%) and oleic acid $(35.5 \%)$ were the dominant fatty acids. Magalhaes et al. (2009) evaluated the phenolic content of hemp, pulp and seeds of quince, and found 5-Ocaffeoylquinic acid acid as the main phenolic acid from the crust (57\%) and pulp (29\%). However, the seeds were rich in stearin-2 (18\%).

\section{Quince leaves}

The leaves of the quinces have healing properties such as the protective effect on spermatogenesis in hypercholesterolaemia (Ashrafi et al., 2013), anti-fungal (Hamid et al., 2013), renoprotective potential (Jouyban et al., 2011), anti-atherogenic, and hepatoprotective potential (Khademi et al., 2013), an anti-proliferative effect on colon cancer cells (Carvalho et al., 2010) and antioxidant potential (Costa et al., 2009) due to the presence of valuable bioactive substances. The leaves from Portuguese quince contain 5-O-caffeolcinic acid (36.2\%), 3,5-O-dicaffeoylquinic acid (3.63\%), 3-Ocaffeocipinic acid (8.93\%), 4-O-caffeoylquinic acid $(0.45 \%)$, quercitin-3-O-rutinoside $(21.1 \%), \quad$ and kaempferol-3-O-rutinoside (12.5\%), quercitin-3-Ogalactoside $(5.56 \%)$, kaempferol-3-O-glycoside $(8.25 \%)$, and kaempferol-3-O-glucoside (3.42\%) as studied using 


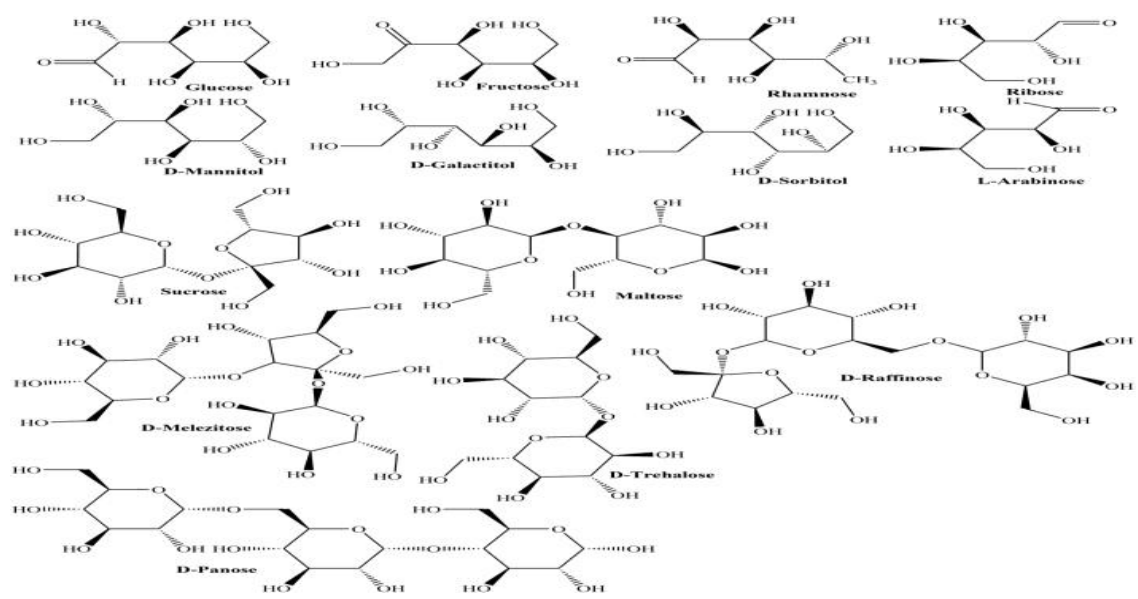

Fig. 2. The structure of important sugars, and sugar alcohols from quince.

HPLC/DAD and HPLC/UV (Oliveira et al., 2007). Similarly, different flavonoids such as quercetin-3-Ogalactoside quercetin-3-O-rutinoside (rutin), kaempferol3-O-glycoside, kaempferol-3- $O$-rutinoside and kaempferol-3-O-glucoside, and phenolic acid, 4- $O$ caffeoylquinic acid were identified in a methanolic extract of leaves from Tunisian quinces.

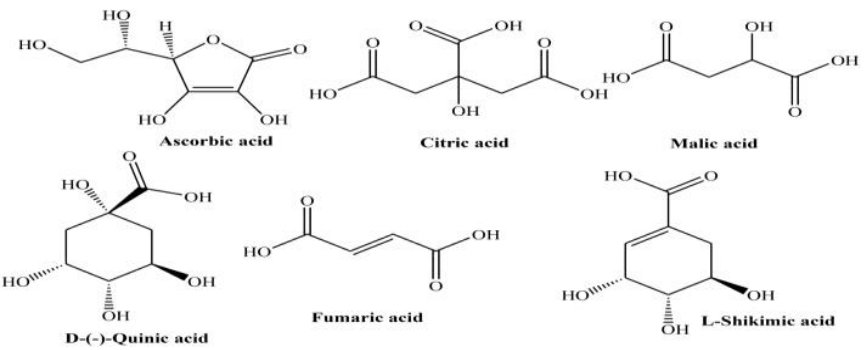

Fig. 3. Structures of some selected acids isolated from various parts of quince.

In addition, rutin (36\%) was the most common flavonoid in its leaves (Benzarti et al., 2015). In another study, chlorogenic acid was identified as the main phenol of quince (Costa et al., 2009). Like phenols, organic acids are also important antioxidant plant metabolites that make them useful for the treatment of various diseases (Silva et al., 2005). The leaves of Central and North Portugal quinces contained D-(-)-quinic acid (72.2\%), oxalic acid $(6.1 \%)$, malic acid $(7.6 \%)$ and citric acid (13.6\%) with small amounts of fumaric and L- shikimic acids that were analyzed using the HPLC/UV method. It was also observed that the leaves collected in June and August had relatively higher acid content than in October (Oliveira et al., 2008). Furthermore, a GC/MS analysis of aqueous distillate of quince leaves was carried out, harvested in flowering (November) and fruiting season (April) for the study of essential oils. The study showed the presence of
47 and 40 different essential oils, representing 95.7 and $64.5 \%$ of the total oils of the leaves collected during flowering and fruiting seasons, respectively. Aldehydes were $12.8 \%$ of total oils in leaves of flowering period followed by fatty acids (hexadecanoic acid 7.2\%), monoterpenes ( $\beta$-linalool 5.7\%), and norisoprenoids like $(E)$ - $\beta$-Ionone $(5.1 \%)$ and $(E, E)-\alpha$-Farnesene $(4.6 \%)$. However, leaves of fruiting quince contained sesquiterpene hydrocarbons (germacrene D 8.6\%), benzaldehyde $(4.9 \%)$, (Z)- $\beta$-Farnesene $(4.8 \%),(Z)-3$ Hexenol $(3.8 \%)$, phytol $(3.1 \%)$, (Z)-3-hexenal $(3.0 \%)$ as major constituents of essential oils (Fig. 4) (Erdogan et al., 2012).

\section{Quince seeds}

Freeze dried seeds collected from North and Central Portugal were evaluated for phenols, free amino acids and organic acids using HPLC/DAD, GC/FID and HPLC/UV. The different phenols that are studied in the seeds of the quinces include 3-,4- and 5-O-caffeoyl quinic acids, 3,5dicaffeoyl quinic acid, apigenin derivatives (vicenin-2, isoschaftoside, and schaftoside), leucenin-2, 6- $C$-pentosyl8-C-glucosyl chrysoeriol, 6- $C$-glucosyl-8- $C$-pentosyl chrysoeriol, and stellarin-2 (Fig. 5). The flavones are a major part of the phytochemical constituents (63-66\%) with isoschaftoside (18\%), caffeoalcinic acids (35-37\%), and 5-O-caffeoylquinic acid (19-24\%) as prominent flavones. The organic acids identified in the seeds of the quinces are fumaric, L-shikimic, D-(-)-quinic, ascorbic, and citric acids.

The total organic acids were found to be $0.8 \mathrm{~g} / \mathrm{kg}$ of the sample. The amino acids identified in frozen dry seeds are L-glycine, L-valine, L-alanine, L-proline, L-leucine, L-isoleucine, L-glutamine acid, L-serine, L-threonine, Lmethionine, L-cysteine, L-phenyl alanine, hydroxyproline, L-asparagine, L-aspartic acid, L-glutamine, ornithine, Ltyrosine, L-histidine, L- tryptophan which comprise about 1.3-1.7 mg/kg sample. In addition, L-aspartic acid, L- 
glutamic acid and L-asparagine are about $60-75 \%$ of the total amino acids (Silva et al., 2005). The phytochemical analysis of ethanol extract from quince seeds showed the presence of tannins, glycosides and phenols ingredients (Al-Khazaraji, 2013).

Methanolic extract of quince seeds was evaluated using different chromatographic and spectroscopic techniques and was observed to consist of 6,8-di-Cglucosyl luteolin (lucenin-2), 6,8-di-C-glucosyl apigenin (vicenin-2), 6,8-di-C-glucosyl chrysoeriol (stellarin-2), 6$C$-arabinosyl-8- $C$-glucosylapigenin (isoschaftoside), 6- $C$ glucosyl-8- $C$-arabinosyl apigenin (schaftoside), 6$C$ pentosyl-8- $C$-glucosyl chrysoeriol, and 6- $C$-glucosyl-8$C$-pentosyl (Ferreres et al., 2003).
A new chromone, 5,7-dihydroxy-2-npentacosanylchromen-4-one and three known components such as ursolic acid, tormentic acid, and $\beta$-daucosterol have been recently isolated from methanolic extract of quince seeds (Ghopur et al, 2012). Quince seed oil was extracted using supercritical fluid (SCF) and ultrasound assisted (UA) extraction techniques to investigate fatty acid profile. The yield of extracted oil was 24.32 and $19.5 \%$ with SCF and UA extractions, respectively. The major components were found to be palmitic, linoleic, stearic, oleic and eicosanoic acids (Daneshvand et al., 2012).

Quince seeds extrude mucilage when soaked in water. Earlier investigations carried out to explore different components of mucilage rendered quince mucilage to be mixture of cellulose and water soluble polysaccharide while acidic hydrolysis revealed the presence of Larabinose, D-xylose, and aldobiouronic acids (Smith and Montgomery, 1959). In this context, Lindberg et al. (1990), explained the structure of a part of the watersoluble mucilite as partly O-acetylated (4-O-methyl-Dglucurono)-D-xylane with a high percentage of glycoronic acid.

\section{Folk medicinal uses}

Traditionally, different parts of plants such as roots, fruits, leaves and seeds are used to treat various diseases. The therapeutic potential of various plant parts is attributed to secondary metabolites such as tannins, terpenoids, alkaloids, etc. (Gilani, 1998). Different parts of quince are often used to relieve various complications. The seeds are used to treat gastrointestinal (GI) disorders such as constipation disorders, diarrhea and respiratory tract disorders including cold wounds, rhinitis and cough (Duke et al., 2002; Nadkarni, 1976). The resulting formulation, Gencydo ${ }^{\circledR}$ containing aqueous extract of quince and lemon juice is used to treat rhinitis and asthma in Europe. The leaves of quince are traditionally used to treat nervousness, dysuria, and insomnia, cough cold cramps in the throat, diarrhea, fever and hyperglycemia (Tabata et al., 1993; Tuzlats and Tolon, 2000). The seed mucilage has been used for healing dermal wounds (Ghafourian et al., 2015).

\section{Pharmacological activities}

\section{Anti-diarrheal activity}

Aqueous-methanolic extract from semen was studied for its spasmolytic/spasmodic activity in an isolated rabbit, jejunum and guinea pig ileum. Seed extract was observed to produces light prokinetic effect at lower concentrations $(0.003-0.03 \mathrm{mg} / \mathrm{mL}$ with EC50 (0.73 $\mathrm{mg} / \mathrm{mL}$ ) and induced muscle relaxation. In addition, the extract successfully eliminated the cleotic smooth muscle spasm caused by $\mathrm{KCl}$ in rabbit jejunum (EC50=0.86 $\mathrm{mg} / \mathrm{mL}$ ) similar to that of verapamil, blocker of a calcium channels. The extract also caused atropine susceptible to a spasmodic effect on an isolated ileum of guinea pig in a concentration of $1-10 \mathrm{mg} / \mathrm{mL}$, which is about $31.22 \pm 3.7 \%$ of control, acetyl choline $(0.3 \mu \mathrm{M})$. This spasmodic effect is due to the activation of muscarinic receptors in the stomach with an extract such as that of acetyl choline. Thus, the quince extract contains spasmodic ingredients that ease constipation. However, the plant extract is needed at a slightly higher concentration $(1-10 \mathrm{mg} / \mathrm{mL})$ for spasmodic effect than spasmolytic action (Janbaz et al., 2013).

\section{Respiratory and gastrointestinal disorders}

Different parts of the quince are used to treat respiratory disorders such as asthma, cough, and bronchitis (Duke et al., 2002; Nadkarni, 1976). In this

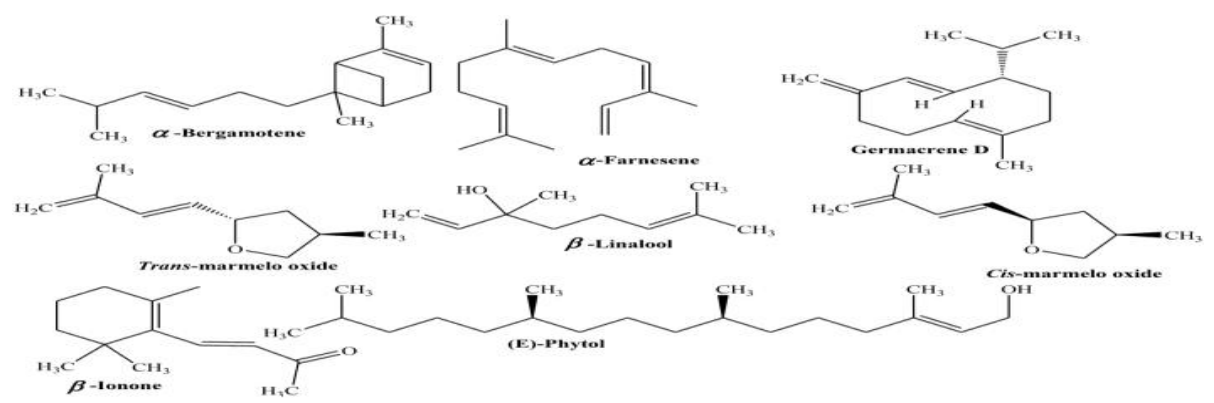

Fig. 4. Structure of selected volatile compounds from quince.

Макед. фарм. билт., 64 (2) 3 - 16 (2018) 


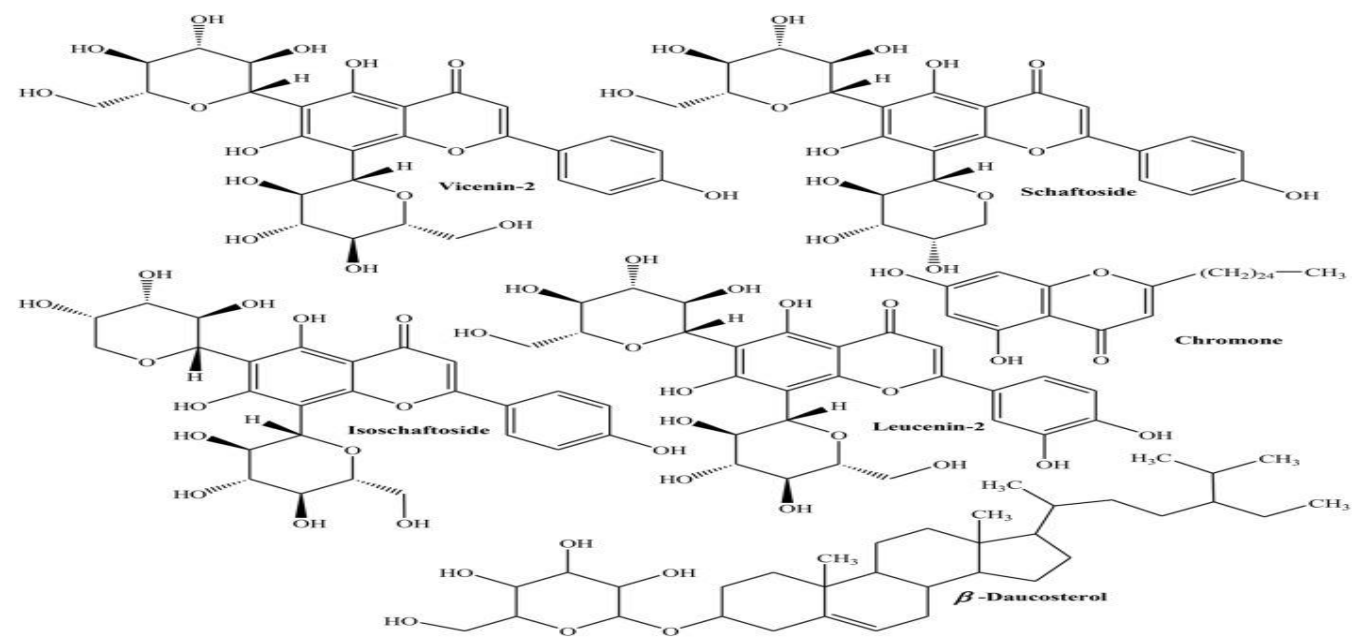

Fig. 5 Selected phytochemicals separated from seeds of quince.

context, a semen extract was applied to an isolated rabbit trachea to assess its activity on the bronchodilator. The results showed the activity of the bronchodilator of the plant extract and thus relieved the spasms of the tracheal smooth muscles induced by $\mathrm{K}^{+}$and carbachol (CCh). The EC50 values were shown to be 0.41 and $0.94 \mathrm{mg} / \mathrm{mL}$ for $\mathrm{K}^{+}$and $\mathrm{CCh}$, respectively. The results were comparable with verapamil. The brontodilator activity of the plant extract can be attributed to the presence of $\mathrm{Ca}^{+}$ antagonistic components (Janbaz et al., 2013). Irritable bowel disease (IBD) is a chronic inflammatory disorder that involves improper activation of the mucosal immune system (McQuaid, 2007, Xavier and Podolsky, 2007). The involvement of ulcerative colitis (UC) and Crohn's disease in IBD is quite possible. Suppression in the activities of antioxidant enzymes has also been observed in IBDs (Nijveldt et al., 2001). Minaiyan et al. (2012) in male Wistar rats at a dose of 200,500 and $800 \mathrm{mg} / \mathrm{kg}$ orally and 200 and $500 \mathrm{mg} / \mathrm{kg}$, have tried to treat IBD with a hydroalcoholic yeast quince fruit extract (QF) intra peritoneal for 5 days. Macroscopic and microscopic analysis showed that both QF significantly reduced bowel damage as standard, dexamethasone. It has also been shown that $\mathrm{QF}$, and dexamethasone are more potent in colon damage at 200 and $800 \mathrm{mg} / \mathrm{kg}$ oral dose, respectively (Minaiyan et al., 2012). Phenols such as chlorogenic acid and flavonoids such as quercetin, rutin and caffeine present in the quince help to repair colorectal damage to the IBD due to their antioxidant and antiinflammatory potential (Chagas-Paula et al., 2011; Chauhan et al., 2011; Nijveldt et al., 2001; Sato et al., 2011).

Quince fruit also contains pectin in significant amounts which protects colon damage in colitis by triggering colonal cell proliferation (Roediger, 2010; Rolandelli et al., 1988). In a double blind clinical study, the effect of quince syrup in alleviating gastro-esophageal reflux disease (GERD) symptoms in children (5-18 years old) was assessed. Quince syrup and omeprazole was administered orally to children at dose 0.6 and $1 \mathrm{cc} / \mathrm{kg} /$ day in quince group and omeprazole group, respectively. After 4 and 7 weeks of therapy, age related questionnaires were filled to assess intensity of symptoms, and cumulative symptoms score (CSS) was compared with that of initial base line. A significant reduction of CSS was noticed in quince group as compared to control group suggesting usefulness of quince syrup in GERD (Zohalinezhad et al., 2015).

\section{Anti-bacterial and antifungal activities}

Helicobacter pylori, a common pathogenic bacterial strain can survive in the acidic environment of stomach and affects $50 \%$ population of world (McGowan et al., 1996; Perry et al., 2006). If the infection is prolonged, it may lead to destruction of gastric mucosa and glands, and specialized cells thereby, increasing the risk of gastric cancer (Correa et al., 1975; Slpponen et al., 1985). Common strategy adopted to treat $H$. pylori is a combination therapy using amoxicillin, clarithromycin, and proton pump inhibitors. In case of allergy to penicillin's, amoxicillin is replaced with metronidazole however bismuth compounds are used in case of resistance to aforementioned antibiotics (Fischbach and Evans, 2007; Graham and Shiotani, 2008; Stenstrom et al., 2008). The resistance of microorganisms to antibiotics urges the researchers to discover new phytomedicines from plants which have been used traditionally for curing different ailments (Della et al., 2002; Heep et al., 2000; Ndip et al., 2007a,b; Nijveldt et al., 2001; Qasim and O'Morain, 2002). In one such attempt, quince juice (10\%) inhibited the growth of $H$. pylori (ATCC 43504) on culambia agar media (ZOI $11 \mathrm{~mm}$ ). A synergistic effect in antibacterial activity of quince juice was observed with blueberry, black chocolate, red currant juice, green tea, 
and sweet flag rhizome (Babarikina et al., 2011). Quince fruit and seeds were extracted with ethanol, acetone and water to study their antimicrobial activity against Escherichia coli, Klebsiella pneumonia, Staphylococcus aureus and Enterobacter aerogenes. Ethanolic extract of quince seeds was most efficient in inhibiting the growth of bacteria. However, aqueous extracts were found least effective against bacteria (Alizadeh et al., 2013a). Similarly, methanolic extract of quince seeds inhibited the growth of Staphylococcus aureus (ZOI $12 \mathrm{~mm}$ ), Staphylococcus epidermidis (ZOI $15 \mathrm{~mm}$ ) and Klebsiella pneumonia (ZOI $8 \mathrm{~mm}$ ) at concentration of 500 and $250 \mathrm{mg} / \mathrm{mL}$, respectively (Alkhazraji, 2013). Moreover, quince fruit ethanolic and acetonic extracts reasonable exhibited anti-fungal potential against Aspergillus niger (Alizadeh et al., 2013b). Acetone and aqueous extracts of quince fruit (peel and pulp) depicted antimicrobial activity due to presence of chlorogenic acid (5-O-caffeoylquinic acid) along other phenolic components (Fattouch et al., 2007). On similar grounds, quince seeds ethanolic and acetonic extracts and silver nanoparticles of seeds mucilage have been evaluated for their potential against Staphylococcus aureus that is causative agent for skin burn infections (Hamid et al., 2014). The study was carried out on mice showing better healing of burn wounds infected with Staphylococcus aureus after topical application of ethanolic and acetonic extracts of quince seeds than that of silver nanoparticles and mupirocin vaseline.

\section{Cardioprotective and hypolipidemic activities}

Cardiovascular diseases (CVD) are associated with diabetes, high blood pressure, atherosclerosis, heart inflammation, and blood clotting. In all aforementioned physiological states, oxidative stress produced by reactive oxygen species (ROS) plays a key role in development of CVD (Griendling and FitzGerald, 2003; Madamanchi et al., 2004; Mueller et al., 2005; Pashkow, 2011). The ROS causing oxidative stress are captured using certain antioxidants to prevent CVDs (Rocha et al., 2010).

The utilization of vegetables and fruits, the best sources for antioxidants (Murcia et al., 2001) decreased risk of CVDs and other degenerative disorders (Fattouch et al., 2007). It was observed in one study that phenolics particularly 5-O-caffeoyl quinic acid present in quince leaves had immense cardio protective potential as it captured ROS (Vaez et al., 2014). The flavonoids, quercitin, and kaempferol-3-O-glucoside (astragalin) and kaempferol-3-O-rutinoside in quince leaves are also cardioprotective (Khoubnasabjafari and Jouyban, 2011). Flavonoids also modulate cardiac inflammation by controlling activation of $\mathrm{T}$ cells, $\mathrm{B}$ cells, mast cells, neutrophils, and basophils. Thus, qiunce leaves could be utilized as natural and economical source that can protect cardiovascular disorders (Middleton and Kandaswami, 1992; Middleton et al., 2000). Current treatment strategies employ statins like atorvastatin to decrease the cholesterol levels in the blood with associated risks of muscular toxicity. Therefore, researchers are looking for medicinal plants such as quince to manage atheroscleroma. Quince has nutritional importance and also regarded as source of phenolics and flavonoids that are medicinally valuable (Costa et al., 2009; Oliveira et al., 2007). Khademi et al. (2013) studied the effect of methanolic fraction of leaf extract on atherosclerosis in white albino rabbits in which atherosclerosis was induced with high cholesterol diet fed for 8 weeks. After 8th week, blood samples were analyzed for serum cholesterol, alanine transaminase (ALT), aspartate transaminase (AST), triglycerides, alanine phosphatase (AP), and histopathology of aorta of normal and high cholesterol fed rabbits. Significant reduction in serum lipids indicates the protective effect of quince extract on atherosclerosis. Moreover, thickness of atheroma in control and treated group animals was found almost similar, showing usefulness of quince extract to prevent plaque formation.

\section{Antioxidant and anti-hemolytic activities}

Oxidation of substances present in biological membrane due to free radicals is associated with different pathological conditions such as aging and cancer (Halliwell and Gutteridge, 1985, 1986). Human erythrocytes have been extensively used to investigate oxidation process involving biological membrane damage (Girotti et al., 1985; Kobayashi et al., 1985). Oxidation process involves membrane, hemoglobin and over all cellular damage. However, hemoglobin is the main site of damage (Goldberg and Stern, 1977). Free radical scavenging agents such as uric acid, ascorbic acid, chromanol, and vitamin E have been successfully used to reduce erythrocyte hemolysis (Niki et al., 1988). It has been established that different ailments such as Parkinson's disease, Alzheimer's, cancer, arteriosclerosis, diabetes, and arthritis are associated with generation of free radicals that cause hemolysis (Labat-Robert and Robert, 2014). In a study, phenolics of methanolic extract of quince fruit seeds, peel, and pulp were isolated using HPLC / UV and evaluated for free radical scavenging abilities using DPPH assay. The potential of extracts to prevent oxidative hemolysis of human erythrocytes induced by 2,2-azobis (2-amidinopropane)dihydrochloride (AAPH) was also studied.

Antioxidant ability of peel $\left(\mathrm{EC}_{50}=0.8 \mathrm{mg} / \mathrm{mL}\right)$ and pulp $\left(\mathrm{EC}_{50}=0.6 \mathrm{mg} / \mathrm{mL}\right)$ extracts was significant and greater than seeds $\left(\mathrm{EC}_{50}=12.2 \mathrm{mg} / \mathrm{mL}\right)$ to prevent erythrocytes hemolysis (Magalhaes et al., 2009). Silva et al. (2004a) carried out qualitative and quantitative analysis of quince fruit (pulp and peel) collected from different regions of Portugal and evaluated their antioxidant potential using DPPH assay. It was observed that phenolic fractions possessed strong free radical scavenging activity than that of organic acid fractions and whole methanolic fractions (Silva et al., 2004a). Phenolic 
composition of fruit and its antioxidant ability provide clear evidence of its medicinal importance. Papp et al. (2013) compared phenolic profile and antioxidant potential of quince peel and fruit of 12 different cultivars and inferred that fruit is a rich source of phenolics with strong antioxidant activity. The cultivars such as "Champion", "De Husi" and "Konstantinapolyi" were found best for scavenging free radicals. The analysis of phenolic contents of aqueous alcoholic extracts using Folin-Ciocalteu reagent depicted appreciable amounts of phenolics (8.55 mg GAE/g FW) in fruit (Papp et al., 2013). Similarly, antioxidant potential of quince fruits pulp and peel of Tunisian quince predicted that peel has higher radical scavenging activity than pulp (Fattouch et al., 2007).

\section{Anti-allergic and anti-inflammatory activities}

Allergy is basically hypersensitivity of immune system to harmless substances like dust, pollens, animal dander, medicines, bee sting, etc. They may enter in the body via skin, inhalation, injection, and ingestion leading to activation of immune system. These allergic responses, if not properly managed may produce certain disorders like dermatitis, rhinitis, anaphylactic shock, and asthma. Different drug therapies to treat allergic disorders including antihistamines, immunosuppressant, and corticosteroids are followed by adverse effects like hypertension, diabetes, osteoporosis, and growth retardation (De Benedictis and Bush, 2012). Thus, researchers are trying to explore plants and food materials with anti-allergic potential with no side effect. In this context, anti-allergic effect of preparations from lemon (Citrus medica L.) and quince fruit were investigated. The extracts showed no anti-allergic effect individually. However, the synergistic effect of both the extracts reduced the degranulation of basophils, production of interleukins IL- 8 and tumor necrosis factor (TNF- $\alpha$ ) from human mast cells significantly (Huber et al., 2012). LCMS analysis showed the presence of eriocitrin and neochlorogenic acid as major phenolics in citrus and quince extracts, respectively.

Gencydo $^{\circledR}$, a combination of lemon juice and quince fruit extract is used traditionally to treat allergic rhinitis or asthma. In a research, it was observed that Gencydo ${ }^{\circledR}$ caused reduction of histamine, IL- 8 , and TNF- $\alpha$ release from mast cells induced by Immunoglobulin-E (IgE) and phorbolmyristate acetate (PM /A23187) in allergic disorders. Furthermore, Gencydo ${ }^{\circledR}$ also blocked eotaxin release from human bronchial epithelial cells. The study supported the use of Gencydo ${ }^{\circledR}$ for the treatment of allergic reactions (Grundemann et al., 2011). Hot water extract of quince fruit was evaluated for alleviation of type-I allergy (atopic dermatitis) in $\mathrm{NC} / \mathrm{Nga}$ mice, divided into control and treated groups. Control group was fed with AIN-93M diet and treated groups received 2.5 and $5 \%$ hot water quince fruit extract for 8 weeks. It was found that control group developed skin dermatitis. Moreover, treated group mice have low IgE level especially with $5 \%$ hot water quince fruit extract $(994 \pm 205 \mathrm{ng} / \mathrm{mL})$ as compared to control $(1635 \pm 289$ $\mathrm{ng} / \mathrm{mL}$ ). The study revealed the anti-allergic potential of quince fruit (Shinomiya et al., 2009). In another study, hot water extract of quince fruit was found effective against $\mathrm{IgE}$ stimulated late phase allergic reactions of mast cells (Kawahara and Lizuka, 2011).

Anti-inflammatory and anti-allergic role of quince fruit peel phenolics has been investigated after aggravating inflammation in human THP-1 cell line by lipopolysaccharide (LPS). Quince fruit peel extract significantly inhibited the release of inflammatory mediators such as cytokines (TNF- $\alpha$ ) and interleukins (IL8) by inducing release of Interleukin-10 and Interleukin-6 from mast cells. The study also exploited that polyphenolic extract from quince peel also inhibited the activation of pro-inflammatory effectors cells by LPS (Essafi-Benkhadir et al., 2012). Anti-inflammatory activity of quince leaf ethanolic extract was also reported by Ahmed and Bastawy (2014). Ethanolic extract of quince leaves was administered orally at concentrations of 25,50 and $100 \mathrm{mg} / \mathrm{kg} 1 \mathrm{~h}$ prior to topical administration of arachidonic acid (2\%) to each ear and $0.1 \mathrm{~mL}$ of carrageenan injection to sub-planer region of paw for induction of paw edema (Winter et al., 1962). Quince leaf extract effectively alleviated symptoms of carrageenan induced paw edema and arachidonic acid induced ear edema in rats (Ahmed and Bastawy, 2014).

\section{Anti-diabetic and renal protective activities}

Diabetes is a common disease that has affected nearly $10 \%$ of population in the world (Bilbis et al., 2002; Irshaid et al., 2012). The disease is characterized by disturbances in fat and protein metabolism leading to hyperlipidemia (Ashraf et al., 2013). Diabetes is also associated with vascular complications which are the major cause of mortality in diabetic patients (Campos, 2012). Quince leaves were extracted with methanol to evaluate its anti-diabetic potential. The findings of study showed that oral administration of extract at dose of $500 \mathrm{mg} / \mathrm{kg}$ body weight decreased blood glucose level $(33.8 \%)$ considerably in streptozotocin induced diabetic rats after 5 days (Aslan et al., 2010).

Hypercholesterolemia not only causes renal injury (Attia et al., 2002; Mune et al., 1999) but also leads to proteinuria, glumerulosclerosis, and masangial cell damage (Eddy, 1996; Joles et al., 2000). This malfunction of glomerulus can be eliminated using antioxidants (Kasiske et al., 1988). Considering, the presence of phenolics in Quince fruit and leaves, and its traditional use to treat different ailments (Fattouch et al., 2007; Oliveira et al., 2007), renoprotective potential of quince leaves decoction has been evaluated in white New Zealand male rabbits divided into three groups (Jouyban et al., 2011). 
Before feeding with normal diet for 6 weeks, group I was fed with high cholesterol diet and group II was administered high cholesterol diet with quince leaf decoction for 6 weeks whereas group III was treated as control group. After this diet, all animals were shifted to their normal diet for another 6 weeks. At the end of this study (12 weeks), urine samples from all groups were collected and ratio of urine protein to creatinine was calculated. All animals were sacrificed to assess the kidney damage due to high cholesterol diet and observed that quince leaf decoction has significantly prevented renal injury in hypercholesterolemic rabbits that might be due to anti-oxidant activity of phenolics present in quince (Jouyban et al., 2011). The renal protective effect of antioxidants and lipid lowering agents in hypercholesterolemia has been well-established (Kasiske et al., 1988; Trovato et al., 2010).

\section{Treatment of industrial wastewater}

The utilization of various synthetic dyes in food, leather, pharmaceutical, rubber and cosmetic industries have been increased for the last many years (Patel and Patel, 2012) thus exposing living organisms to various diseases like cancer (Nandi et al., 2009). Nowadays, researchers are interested to get rid of these industrial wastes using inexpensive and energy efficient enzymatic degradation method than chemical methods (Eichlerova et al., 2006; Hamid et al., 2013; Pengthamkeerati et al., 2010). Oxido-reductase enzymes such as polyphenoloxidases (PPO) and peroxidases of microbial and plant origin are being widely used (Bhunia et al., 2001; Husain and Jan, 2000). In a study, the comparison of free and immobilized PPO on calcium alginate beads obtained from quince leaves was carried out. The stability of free and immobilized enzyme was evaluated at different $\mathrm{pH}$ range (3.5-9.0). The optimum stability was observed at $\mathrm{pH} 7.5$ however immobilized enzyme was found to be more stable at different $\mathrm{pH}$ ranges than free enzyme. The immobilized PPO was found to be more thermally stable than free. The decolorization activity of both free and immobilized PPO was optimum between $\mathrm{pH}$ (4.0-7.0) after which it was noticed to drop off (Arabaci and Usluoglu, 2014).

\section{Conclusion}

Cydonia oblonga is medicinal plant of family Rosaceae which has attracted the researchers owing to its folk medicinal uses and high-valued bioactive. Besides pharmaceutical attributes, the plant is also popular because of renoprotecticve, hepatoprotective, antidiabetic, anti-proliferative, anti-hemolytic, antiinflammatory, anti-allergic, geno-protective, and cardioprotective activities. Protective effect of its leaves on male fertility has been established. Hence, there is immense need to isolate potential bioactives from Quince for the development of new safer and economical drugs.

Moreover, plant is rich source of pectin used in food industry in the preparation of jams and jellies. The plant also contains PPO enzyme which is used to decolorize industrial waste thus providing cost effective alternate to treat industrial water. The plant should be cultivated to isolate pectin and PPO enzyme on commercial basis. Glucuronoxylan polysaccharide from seeds of plant has been used for preparation of dermal films to cure wounds. Cytotoxic investigations are required to establish its safety profile to prepare dermal patches. Furthermore, glucuronoxylan could be the potential candidate for controlled/sustained/targeted drug deliveries after toxicological studies.

Resistance of microorganisms to antibiotics is an emerging issue. Thus, there is a need to develop new antibiotics for the treatment of various ailments. Various literature reports indicated that Quince is rich in microbistatic agents and can be the choice for the isolation of new phytochemicals to introduce new drugs. Several cytotoxic studies revealed that plant has a potential to cure cancer. However, further in vivo models should be employed to confirm its anti-proliferative tendency before human trials. The isolation of active anticancerous secondary metabolites is also demanding. As a functional food, Quince is rich in minerals like sodium, potassium, phosphorous, etc. and essential oils. So there is a need to standardize and validate its medicinal applications as potential source for nutraceuticals.

\section{References}

Ahmed, M.M., Bastawy, S., 2014. Evaluation of antiinflammatory properties and possible mechanism of action of Egyptian quince (Cydonia oblonga) leaf. Egypt. J. Biochem. Mol. Biol. 32, 190-205.

Aksic, M.F., Tosti, T., Nedic, N., Markovic, M., Licina, V., Milojkovic-Opsenica, D., Tesic, Z., 2015. Influence of frost damage on the sugars and sugar alcohol composition in quince (Cydonia oblonga Mill) floral nectar. Acta Physiol. Plant. 37, 1-11. Available at: https://doi.org/10.1007/s11738-014-1701-y.

Alizadeh, H., Ajalli, M., Hossein, H., 2013b. Antifungal effect of Cydonia oblonga extracts on Aspergillus niger. Jundishapur J. Microbiol. 2013, 4.

Alizadeh, H., Rahnema, M., Semnanai S.N., Hajizadeh, N., 2013a. Detection of compounds and antibacterial effect of Quince (Cydonia oblonga Miller) extracts in vitro and in vivo. J. Biol. Active Prod. Nat. 3, 303-309. Available at: https://doi.org/10.1080/22311866.2013.817731.

Al-khazraji, S.K., 2013. Phytochemical screening and antibacterial activity of the crude extract of Cydonia oblonga seeds. Glob. Adv. Res. J. Microbiol. 2, 137-140.

Ammar, S., Edziri, H., Mahjoub, M.A., Chatter, R., Bouraoui, A., Mighri, Z., 2009. Spasmolytic and anti-inflammatory effects of constituents from Hertia cheirifolia. 
Phytomedicine 16, 1156-1161. Available at: https://doi.org/10.1016/j.phymed.2009.03.012.

Anwar, F., Muhammad, G., Hussain, M.A., Zengin, G., Alkharfy, K.M., Ashraf, M., Gilani, A.H., 2016. Capparis spinosa L.: a plant with high potential for development of functional foods and nutraceuticals/pharmaceuticals. Int. J. Pharmacol. 12, 201-219. Available at: https://doi.org/org/10.3923/ijp.2016.201.219.

Arabaci, G., Usluoglu, A., 2014. The enzymatic decolorization of textile dyes by the immobilized polyphenol oxidase from Quince leaves. Sci. World J. 685975. Available at: https://doi.org/10.1155/2014/685975.

Ashraf, H., Heidari, R., Nejati, V., Ilkhanipoor, M., 2013. Effects of aqueous extract of Berberis integerrima root on some physiological parameters in streptozotocin-induced diabetic rats. Iran. J. Pharm. Res. 12, 425-434.

Ashrafi, H., Ghabili, K., Alihemmati, A., Jouyban, A., Shoja, M.M., Aslanabadi, S., Adl, F.H., Ghavimi, H., Hajhosseini, L., 2013. The effect of quince leaf (Cydonia oblonga Miller) decoction on testes in hypercholesterolemic rabbits: a pilot study. Afr. J. Tradit. Complement. Alter. Med. 10, 277-282. Available at: https://doi.org/10.4314/ajtcam.v10i2.12.

Aslan, M., Orhan, N., Orhan, D.D., Ergun, F., 2010. Hypoglycemic activity and antioxidant potential of some medicinal plants traditionally used in Turkey for diabetes. J. Ethnopharmacol. 128, 384-389. Available at: https://doi.org/10.1016/j.jep.2010.01.040.

Attia, D.M., Ni, Z.N., Boer, P., Attia, M.A., Goldschmeding, R., Koomans, H.A., Vaziri, N.D., Joles, J.A., 2002. Proteinuria is preceded by decreased nitric oxide synthesis and prevented by a NO donor in cholesterol-fed rats. Kidney Int. 61, 1776-1787. Available at: https://doi.org/10.1046/j.1523-1755.2002.00313.x.

Babarikina, A., Nikolajeva, V., Babarykin, D., 2011. AntiHelicobacter activity of certain food plant extracts and juices and their composition in vitro. Food Nut. Sci. 2, 868-877. Available at: https://doi.org/10.4236/fns.2011.28118.

Banerjee, G., Car, S., Scott-Craig, J.S., Hodge, D.B., Walton J.D., 2011. Alkaline peroxide pretreatment of corn stover: effects of biomass, peroxide, and enzyme loading and composition on yields of glucose and xylose. Biotech. Biofuels. 4, 16-30. Available at: https://doi.org/10.1186/1754-6834-4-16.

Benzarti, S., Hamdi, H., Lahmayer, I., Toumi, W., Kerkeni, A., Belkadhi, K., Sebei, H., 2015. Total phenolic compounds and antioxidant potential of quince (Cydonia oblonga Miller) leaf methanol extract. Int. J. Inov. Appl. Stud. 13, 518-526.

Bhunia, A., Durani, S., Wangikar, P.P., 2001. Horseradish peroxidase catalyzed degradation of industrially important dyes. Biotech. Bioeng. 72, 562-567. Available at: https://doi.org/10.1002/10970290(20010305)72:5<562::AID-BIT1020>3.0.CO;2-S.

Bilbis, L.S., Shehu, R.A., Abubakar, M.G., 2002. Hypoglycemic and hypolipidemic effects of aqueous extract of Arachis hypogaea in normal and alloxan-induced diabetic rats. Phytomedicine 9, 553-555. Available at: https://doi.org/10.1078/09447110260573191.

Budriesi, R., Ioan, P., Micucci, M., Micucci, E., Limongelli, V., Chiarini, A., 2010. Stop Fitan: antispasmodic effect of natural extract of chestnut wood in guinea pig ileum and proximal colon smooth muscle. J. Med. Food 13, 11041110. Available at: https://doi.org/10.1089/jmf.2009.0210.

Campos, C., 2012. Chronic hyperglycemia and glucose toxicity: pathology and clinical sequelae.Postgrad. Med. 124, 9097. Available at: https://doi.org/10.3810/pgm.2012.11.2615.

Carvalho, M., Silva, B.M., Silva, R., Valentao, P., Andrade, P.B., Bastos, M.L., 2010. First report on Cydonia oblonga Miller anticancer potential: differential antiproliferative effect against human kidney and colon cancer cells. J. Agric. Food Chem. 58, 3366-3370. Available at: https://doi.org/10.1021/jf903836k.

Chagas-Paula, D.A., De-Oliveira, R.B., Da-Silva, V.C., GobboNeto, L., Gasparoto, T.H., Campanelli, A.P., Faccioli, L.H., Da Costa, F.B., 2011. Chlorogenic acids from Tithonia diversifolia demonstrate better antiinflammatory effect than indomethacin and its sesquiterpene lactones. J. Ethnopharmacol. 136, 355-362. Available at: https://doi.org/10.1016/j.jep.2011.04.067.

Chauhan, P.S., Satti, N.K., Sharma, V.K., Dutt, P., Suri, K.A., Bani, S., 2011. Amelioration of inflammatory responses by chlorogenic acid via suppression of pro-inflammatory mediators. J. Appl. Pharm. Sci. 1, 67-75.

Correa, P., Haenszel, W., Cuello, C., Tannenbaum, S., Archer, M., 1975. A model for gastric cancer epidemiology. Lancet 2, 58-60. Available at: https://doi.org/10.1016/S0140-6736(75)90498-5.

Costa, R.M., Magalhaes, AS., Pereira, J. A., Andrade, P.B., Valentao, P., Carvalho, M., Silva, B.M., 2009. Evaluation of free radical-scavenging and anti-hemolytic activities of quince (Cydonia oblonga) leaf: a comparative study with green tea (Camellia sinensis). Food Chem. Toxicol. 47, 860-865. Available at: https://doi.org/10.1016/j.fct.2009.01.019.

Daneshvand, B., Ara, K.M., Raofie, F., 2012. Comparison of supercritical fluid extraction and ultrasound-assisted extraction of fatty acids from quince (Cydonia oblonga Miller) seed using response surface methodology and central composite design. J. Chromatogr. A 1252, 17. Available at: https://doi.org/10.1016/j.chroma.2012.06.063.

De Benedictis, F.M., Bush, A., 2012. Corticosteroids in respiratory diseases in children. Am. J. Resp. Crit. Care Med. 185, 12-23. Available at: https://doi.org/10.1164/rccm.201107-1174CI.

Della, M.P., Lavagna, A., Masoero, G., Lombardo, L., Crocella, L., Pera, A., 2002. Effectiveness of Helicobacter pylori eradication treatments in a primary care setting in Italy. Aliment. Pharmacol. Ther. 16, 1269-1275. Available at: https://doi.org/10.1046/j.1365-2036.2002.01244.x.

De Tommasi, N., De Simone, F., Pizza, C., Mahmood, N., 1996. New tetracyclic sesterterpenes from Cydonia vulgaris. J. Nat. Prod. 59, 267-270. Available at: https://doi.org/10.1021/np9600513.

Duke, J.A., Bogenschutz-Godwin, M.J., Ducelliar, J., Duke, P.A.K., 2002. Handbook of Medicinal Herbs, second ed. FL: CRC Press, Boca Raton.

Eddy, A.A., 1996. Interstitial inflammation and fibrosis in rats with diet induced hypercholesterolemia. Kidney Int. 50, 1139-1149. Available at: https://doi.org/10.1038/ki.1996.421. 
Eichlerova, I., Homolka, L., Nerud, F., 2006. Synthetic dye decolorization capacity of white rot fungus Dichomitus squalens. Bioresour. Technol. 97, 2153-2159. Available at: https://doi.org/10.1016/j.biortech.2005.09.014.

Erdogan, T., Gonenç, T., Hortoglu, Z.S., Demirci, B., Başer, K.H.C., Kıvçak, B., 2012. Chemical composition of the essential oil of quince (Cydonia Oblonga Miller) leaves. Med. Aromat. Plants 1, 134. Available at: https://doi.org/10.4172/2167-0412.1000e134.

Essafi-Benkhadir, K., Refai, A., Riahi, I., Fattouch, S., Karoui, H., Essafi, M., 2012. Quince (Cydonia oblonga Miller) peel polyphenols modulate LPS-induced inflammation in human THP-1-derived macrophages through NF- $\kappa$ B, p38MAPK and Akt inhibition. Biochem. Biophy. Res. Commun. 418, 180-185. Available at: https://doi.org/10.1016/j.bbrc.2012.01.003.

Evans, W.C., Evans, D., Trease, G.E., 2002. Trease and Evans pharmacognosy, 15th ed. NY: WB Saunders, New York.

Fattouch, S., Caboni, P., Coroneo, V., Tuberoso, C.I., Angioni, A., Dessi, S., Marzauki, N., Cabras, P., 2007. Antimicrobial activity of Tunisian quince (Cydonia oblonga Miller) pulp and peel polyphenolic extracts. J. Agric. Food Chem. 55, 963-969. Available at: https://doi.org/10.1021/jf062614e.

Ferreres, F., Silva, B.M., Andrade, P.B., Seabra, R.M., Ferreira, M.A., 2003. Approach to the study of C-glycosyl flavones by ion trap HPLC-PAD-ESI / MS / MS: application to seeds of Quince (Cydonia oblonga). Phytochem. Anal. 14, 352-359. Available at: https://doi.org/10.1002/pca.727.

Fischbach, L., Evans, E.L., 2007. Meta-analysis: the effect of antibiotic resistance status on the efficacy of triple and quadruple first-line therapies for Helicbacter pylori. Aliment. Pharmacol. Ther.26, 343-357. Available at: https://doi.org/10.1111/j.1365-2036.2007.03386.x.

Ghafourian, M., Tamri, P., Hemmati, A., 2015. Enhancement of human skin fibroblasts proliferation as a result of treating with quince seed mucilage. Jundishapur J. Nat. Pharm. Prod. 10. Available at: https://doi.org/e18820-e18823. 10.17795/jjnpp-18820.

Gheisari, H.R., Abhari, K.H., 2014. Drying method effects on the antioxidant activity of quince (Cydonia oblonga Miller) tea. Acta Sci. Pol. Technol. Aliment. 13, 129-134. Available at: https://doi.org/10.17306/J.AFS.2014.2.2.

Gholgholab, H., 1961. Ghiah (in Farsi). Tehran: Tehran University Press.

Ghopur, H., Usmanova, S.K., Ayupbek, A., Aisa, H.A., 2012. A new chromone from seeds of Cydonia oblonga. Chem. Nat. Comp. 48, 562-564. Available at: https://doi.org/10.1007/s10600-012-0310-5.

Gilani, A.H., 1998. Novel developments from natural products in cardiovascular research. Phytother. Res. 12, 66-69. Available at: https://doi.org/10.1002/(SICI)10991573(1998)12:1+<S66::AID-PTR253>3.0.CO;2-W.

Gilani, A.H., Rahman, A.U., 2005. Trends in ethnopharmacology. J. Ethnopharmacol. 100, 43-49. Available at: https://doi.org/10.1016/j.jep.2005.06.001.

Girotti, A.W., Thomas, J.P., Jordan, J.E., 1985. Lipid photooxidation in erythrocyte ghosts: sensitization of the membranes toward ascorbate-and superoxide-induced peroxidation and lysis.Arch. Biochem. Biophys. 236, 238251. Available at: https://doi.org/10.1016/00039861(85)90623-X.

Goldberg, B., Stern, A., 1977. The role of the superoxide anion as a toxic species in the erythrocyte. Arch. Biochem. Biophys. 178, 218-225. Available at: https://doi.org/10.1016/0003-9861(77)90187-4.

Graham, D.Y., Shiotani, A., 2008. New concepts of resistance in the treatment of Helicobacter pylori infections. Nat. Clin. Pract. Gastroenterol. Hepatol. 5, 321-331. Available at: https://doi.org/10.1038/ncpgasthep1138.

Griendling, K.K., FitzGerald, G. A., 2003. Oxidative stress and cardiovascular injury: part II: animal and human studies. Circulation 108, 2034-2040. Available at: https://doi.org/10.1161/01.CIR.0000093661.90582.c4.

Grundemann, C., Papagiannopoulos, M., Lamy, E., Sundermann, V.M., Huber, R., 2011. Immunomodulatory properties of a lemon-quince preparation (Gencydo ${ }^{\circledR}$ ) as an indicator of anti-allergic potency. Phytomedicine 18, 760768. Available at: https://doi.org/10.1016/j.phymed.2010.11.016.

Halliwell, B., Gutteridge, J.M., 1985. The importance of free radicals and catalytic metal ions in human diseases. Mol. Aspects Med. 8, 89-193. Available at: https://doi.org/10.1016/0098-2997(85)90001-9.

Halliwell, B., Gutteridge, J.M., 1986. Oxygen free radicals and iron in relation to biology and medicine: some problems and concepts. Arch. Biochem. Biophys. 246, 501-514. Available at: https://doi.org/10.1016/0003-9861(86)90305$\mathrm{X}$.

Hamauzu, Y., Irie, M., Kondo, M., Fujita, T., 2008. Antiulcerative properties of crude polyphenols and juice of apple and Chinese quince extracts. Food Chem. 108, 488495. Available at: https://doi.org/10.1016/j.foodchem.2007.10.084.

Hamid, H.F., Moezzi, A., Khouzani, M.A., MahmoudJanlou, Y., Niknejad, F., Faramarzi, M.A., 2013. Synthetic dye decolorization by three sources of fungal laccase. Res. J. Chem. Environ. 17, 76-81. Available at: https://doi.org/10.1186/1735-2746-9-27.

Hamid, A., Mehdi, R., Shahrzad, N. S., Ajalli, M., 2014. Synergistic antifungal effects of quince leaf's extracts and silver nanoparticles on Aspergillus niger. J. Appl. Biol. Sci. 8, 10-13.

Heep, M., Kist, M., Strobel, S., Beck, D., Lehn, N., 2000. Secondary resistance among 554 isolates of Helicobacter pylori after failure of therapy. Eur. J. Clin. Microbiol. Infect. Dis. 19, 538-541. Available at: https://doi.org/10.1007/s100960000288.

Hopur, H., Asrorov, A.M., Qingling, M., Yili, A., Ayupbek, A., Nannan, P., Aisa, H.A., 2011. HPLC Analysis of polysaccharides in Quince (Cydonia Oblonga Mill. var. maliformis) fruit and PTP1B inhibitory activity. Nat. Prod. J. 1, 146-150. Available at: https://doi.org/10.2174/2210315511101020146.

Huber, R., Stintzing, F. C., Briemle, D., Beckmann, C., Meyer, U., Grundemann, C., 2012. In-vitro anti-allergic effects of aqueous fermented preparations from Citrus and Cydonia fruits. Planta Med. 78, 334-340. Available at: https://doi.org/10.1055/s-0031-1280455.

Husain, Q., Jan, U., 2000. Detoxification of phenols and aromatic amines from polluted waste water by using phenol oxidases. J. Sci. Ind. Res. 59, 286-293.

Huxley, A., Griffiths, M., Levy, M., 1999. The New RHS Dictionary of Gardening Grove's Dictionaries. Paper and slipcase Edn., London.

Irshaid, F., Mansi, K., Bani-Khaled, A., Aburjia, T., 2012. 
Hepatoprotetive, cardioprotective and nephroprotective actions of essential oil extract of Artemisia sieberi in alloxan induced diabetic rats. Iran. J. Pharm. Res. 11, $1227-1234$

Janbaz, K., Shabbir, A., Mehmood, M.H., Gilani, A.H., 2013. Insight into mechanism underlying the medicinal use of Cydonia oblonga in gut and airways disorders. J. Animal Plant Sci. 23, 330-336.

Joles, J.A., Kunter, U.T.A., Janssen, U.L.F., Kriz, W., Rabelink, T.J., Koomans, H.A., Floege, J., 2000. Early mechanisms of renal injury in hypercholesterolemic or hypertriglyceridemic rats. J. Am. Soc. Nephrol. 11, 669683.

Jouyban, A., Shoja, M.M., Ardalan, M.R., Khoubnasabjafari, M., Sadighi, A., Tubbs, R.S., Agutter, P.S., Ghabili, K., 2011. The effect of quince leaf decoction on renal injury induced by hypercholesterolemia in rabbits: a pilot study. J. Med. Plants Res. 5, 5291-5295.

Kasiske, B.L., O'Donnell, M.P., Garvis, W.J., Keane, W.F., 1988. Pharmacologic treatment of hyperlipidemia reduces glomerular injury in rat 5/6 nephrectomy model of chronic renal failure. Circ. Res. 62, 367-374.

Kawahara, T., Lizuka, T., (2011). Inhibitory effect of hot-water extract of quince (Cydonia oblonga) on immunoglobulin E-dependent late-phase immune reactions of mast cells. Cytotechnology 63, 143-152. Available at: https://doi.org/10.1007/s10616-010-9323-8.

Khademi, F., Danesh, B., Nejad, M.D., Rad, J.S., 2013. The comparative effects of atorvastatin and quince leaf extract on atherosclerosis. Iran. Red Cres. Med. J. 15, 639-643. Available at: https://doi.org/10.5812/ircmj.4030.

Khoubnasabjafari, M., Jouyban, A., 2011. A review of phytochemistry and bioactivity of quince (Cydonia oblonga Mill). J. Med. Plants Res. 5, 3577-3594.

Kirimer, N., Tunalier, Z., Can, B.K.H., Cingi, I., 1997. Antispasmodic and spasmogenic effects of Scolymus hispanicus and taraxasteryl acetate on isolated ileum preparations. Planta Med. 63, 556-558. Available at: https://doi.org/10.1055/s-2006-957765.

Kobayashi, T., Itabe, H., Inoue, K., Nojima, S., 1985. Peroxidation of liposomes in the presence of human erythrocytes and induction of membrane damage of erythrocytes by peroxidized liposomes. Biomembranes 814, 170-178. Available at: https://doi.org/10.1016/00052736(85)90433-X.

Kusari, S., Singh, S., Jayabaskaran, C., 2014. Re-thinking production of $\operatorname{Taxol}^{\circledR}$ (paclitaxel) using endophyte biotechnology. Trends Biotechnol. 32, 304-311. Available at: https://doi.org/10.1016/j.tibtech.2014.03.011.

Labat-Robert, J., Robert, L., 2014. Longevity and aging. role of free radicals and xanthine oxidase. a review. Pathol. Biol. 62, 61-66. Available at: https://doi.org/10.1016/j.patbio.2014.02.009.

Lattanzio, V., Kroon, P.A., Linsalata, V., Cardinali, A., 2009. Globe artichoke: a functional food and source of nutraceutical ingredients. J. Func. Foods 1, 131-144. Available at: https://doi.org/10.1016/j.jff.2009.01.002.

Lindberg, B., Mosihuzzaman, M., Nahar, N., Abeysekera, R.M., Brown, R.G., Willison, J.H.M., 1990. An unusual (4-Omethyl-O-glucurono)-O-xylan isolated from the mucilage of seeds of the quince tree (Cydonia oblonga). Carbohyd. Res. 207, 307-310. Available at: https://doi.org/10.1016/0008-6215(90)84057-2.
Lutz-Roder, A., Schneider, M., Winterhalter, P., 2002. Isolation of two new ionone glucosides from quince (Cydonia oblonga Miller) leaves. Nat. Prod. Lett. 16, 119-122. Available at: https://doi.org/10.1080/10575630290020028.

Madamanchi, N.R., Vendrov, A., Runge, M.S., 2004. Oxidative stress and vascular disease.Arterioscler. Thromb. Vasc. Biol. 25, 29-38. Available at: https://doi.org/10.1161/01.ATV.0000150649.39934.13.

Magalhaes, A.S., Siva, B.M., Pereira, J.A., Andrade, P.B., Valentao, P., Carvalho, M., 2009. Protective effect of Quince (Cydonia oblonga Miller) fruit against oxidative hemolysis of human erythrocytes. Food Chem. Toxicol. 47, 1372-1377. Available at: https://doi.org/10.1016/j.fct.2009.03.017.

Marwat, S.K., Khan, M.A., Khan, M.A., Ahmad, M., Zafar, M., Fazal-ur-rehman, Sultana, S., 2009. Fruit plant species mentioned in the Holy Qura'n and Ahadith and their ethnomedicinal importance. Am. Eurasian J. Agric. Environ. Sci. 5, 284-295.

McGowan, C.C., Cover, T.L., Blaser, M.J., 1996. Helicobacter pylori and gastric acid: biological and therapeutic implications. Gastroenterology 110, 926-938. Available at: https://doi.org/10.1053/gast.1996.v110.pm8608904.

McQuaid, K.R., 2007. Drugs used in the treatment of gastrointestinal disease, in Basic and Clinical Pharmacology, in: Katzung B. G. (Eds.), 10th ed. NY: McGraw Hill Companies, New York, pp. 1029-1035.

Middleton, E., Kandaswami, C., 1992. Effects of flavonoids on immune and inflammatory cell functions. Biochem. Pharmacol. 43, 1167-1179. Available at: https://doi.org/10.1016/0006-2952(92)90489-6.

Middleton, E., Kandaswami, C., Theoharides, T.C., 2000. The effects of plant flavonoids on mammalian cells: implications for inflammation, heart disease, and cancer. Pharmacol. Rev. 52, 673-751.

Minaiyan, M., Ghannadi, A., Etemad, M., Mahzouni, P., 2012. A study of the effects of Cydonia oblonga Miller (Quince) on TNBS-induced ulcerative colitis in rats. Res. Pharm. Sci. 7, 103-110.

Mueller, C.F., Laude, K., McNally, J.S., Harrison, D.G., 2005. ATVB in focus: redox mechanisms in blood vessels. Arterioscler. Thromb. Vasc. Biol. 25, 274-278. Available at: https://doi.org/10.1161/01.ATV.0000149143.04821.eb.

Muhammad, G., Hussain, M.A., Anwar, F., Ashraf, M., Gilani, A.H., 2014. Alhagi: a plant genus rich in bioactives for pharmaceuticals. Phytother. Res. 29, 1-13. Available at: https://doi.org/10.1002/ptr.5222.

Muhammad, G., Hussain, M.A., Jantan, I., Bukhari, S.N.A., 2016. Mimosa pudica L., a high-value medicinal plant as a source of bioactives for pharmaceuticals. Compr. Rev. Food Sci. Food Saf. 15, 303-315. Available at: https://doi.org/10.1111/1541-4337.12184.

Mune, M., Meydani, M., Gong, J., Fotouhi, N., Ohtani, H., Smith, D., Blumberg, J.B., 1999. Effect of ietary fish oil, vitamin E, and probucol on renal injury in the rat. J. Nutr. Biochem. 10, 539-546. Available at: https://doi.org/10.1016/S0955-2863(99)00042-X.

Murcia, M.A., Jimenez, A.M., Martinez-Tome, M., 2001. Evaluation of the antioxidant properties of Mediterranean and tropical fruits compared with common food additives. J. Food Prot. 64, 2037-2046. 
Nadkarni, K.M., 1976. Indian Materia Medica with Ayurvedic, Unani-tibbi, Siddha, Allopathic, Homeopathic, Naturopathic \& Home Remedies, Appendices \& Indexes, third ed. Popular Prakashan, Bombay.

Nandi, B.K., Goswami, A., Purkait, M.K., 2009. Adsorption characteristics of brilliant green dye on kaolin. J. Hazard. Mat. 161, 387-395. Available at: https://doi.org/10.1016/j.jhazmat.2008.03.110.

Ndip, R.N., Tarkang, A.E., Echakachi, C.M., Malongue, A., Akoachere, J.F., Ndip, L.M., Luma, H.N., 2007a. In vitro antimicrobial activity of selected honeys on clinical isolates of Helicobacter pylori. Afr. Health Sci. 7, 228231.

Ndip, R.N., Tarkang, A.E.M., Mbullah, S.M., Luma, H.N., Malongue, A., Ndip, L.M., Nvongbelak, K., Wirmum, C., efange, S.M., 2007b. In vitro anti-Helicobacter pylori activity of extracts of selected medicinal plants from North West Cameroon. J. Ethnopharmacol. 114, 452-457. Available at: https://doi.org/10.1016/j.jep.2007.08.037.

Nijveldt, R.J., Van-Nood, E., Van-Hoorn, D.E., Boelens, P.G., Van-Norren, K., Van-Leeuwen, P.A., 2001. Flavonoids: a review of probable mechanisms of action and potential applications. Am. J. Clin. Nutr. 74, 418-425.

Niki, E., Komuro, E., Takahashi, M., Urano, S., Ito, E., Terao, K., 1988. Oxidative hemolysis of erythrocytes and its inhibition by free radical scavengers. J. Biol. Chem. 263, 19809-19814.

Oliveira, A.P., Pereira, J.A., Andrade, P.B., Valentao, P., Seabra, R.M., Silva, B.M., 2007. Phenolic profile of Cydonia oblonga Miller leaves, J. Agric. Food Chem. 55, 7926-7930. Available at: https://doi.org/10.1021/jf0711237.

Oliveira, A.P., Pereira, J.A., Andrade, P.B., Valentao, P., Seabra, R.M., Silva, B.M., 2008. Organic acid composition of Cydonia oblonga Miller leaf. Food Chem. 111, 393-399. Available at: https://doi.org/10.1016/j.foodchem.2008.04.004.

Papp, N., Szabo, T., Szabo, Z., Nyeki, J., Stefanovits-Banyai, E.I., Hegedus, A., 2013. Antioxidant capacity and total polyphenolic content in quince (Cydonia oblonga Mill) fruit. Int. J. Hort. Sci. 19, 33-36. Available at: https://doi.org/10.31421/IJHS/19/3-4./1099.

Pashkow, F.J., 2011. Oxidative stress and inflammation in heart disease: do antioxidants have a role in treatment and / or prevention. Int. J. Inflam. 2011:514623. Available at: https://doi.org/10.4061/2011/514623.

Patel, P.N., Patel, H.S., 2012. Removal and decolorization of dye bearing textile effluents by sulfinated furfural-acetone resin. Adv. Appl. Sci. Res. 3, 2693-2699.

Pengthamkeerati, P., Satapanajaru, T., Chatsatapattayakul, N., Chairattanamanokorn, P., Sananwai, N., 2010. Alkaline treatment of biomass fly ash for reactive dye removal from aqueous solution. Desalination 261, 34-40. Available at: https://doi.org/10.1016/j.desal.2010.05.050.

Perry, S., Sanchez, M.L., Yang, S., Haggerty, T., Hurst, P., Perez-Perez, G., Parsonnet, J., 2006. Gastroenteritis and transmission of Helicobacter pylori infection in households. Emerg. Infect. Dis.12, 1701-1708. Available at: https://doi.org/10.3201/eid1211.060086.

Prajapati, N.D., Purohit, S.S., Sharma, A.K., Kumar, T., 2006. A Handbook of Medicinal Plants. Jodhpur: Agrobios, Section II, 86.

Qasim, A., O'Morain, C.A., 2002. Review article: treatment of Helicobacter pylori infection and factors influencing eradication. Aliment Pharmacol. Ther. 16, 24-30. Available at: https://doi.org/10.1046/j.1365-2036.2002.0160s1024.x.

Rocha, M., Apostolova, N., Hernandez-Mijares, A., Herance, R., Victor, V.M., 2010. Oxidative stress and endothelial dysfunction in cardiovascular disease: mitochondriatargeted therapeutics. Curr. Med. Chem. 17, 3827-3841. Available at: https://doi.org/10.2174/092986710793205444.

Roediger, W.E., 2010. The starved colon diminished mucosal nutrition, diminished absorption, and colitis. Dis. Colon Rect. 33, 858-862. Available at: https://doi.org/10.1007/BF02051922.

Rolandelli, R.H., Saul, S.H., Settle, R.G., Jacobs, D.O., Trerotola, S.O., Rombeau, J.L., 1988. Comparison of parenteral nutrition and enteral feeding with pectin in experimental colitis in the rat. Am. J. Clin. Nutr. 47, 715721.

Rop, O., Balik, J., Reznicek, V., Jurikova, T., Skardova, P., Salas, P., Sochor, J., Mlcek, J., Kramarova, D., 2011. Chemical characteristics of fruits of some selected quince (Cydonia oblonga Miller) cultivars. Cazech J. Food Sci. 29, 65-73. Available at: https://doi.org/10.17221/212/2009-CJFS.

Russell, W., Duthie, G., 2011. Plant secondary metabolites and gut health: the case for phenolic acids. Proc. Nutr. Soc. 70, 389-396. Available at: https://doi.org/10.1017/S0029665111000152.

Sato, Y., Itagaki, S., Kurokawa, T., Ogura, J., Kobayashi, M., Hirano, T., Sugawara, M., Iseki, K., 2011. In-vitro and Invivo antioxidant properties of chlorogenic acid and caffeic acid. Int. J. Pharm. 403, 136-138. Available at: https://doi.org/10.1016/j.ijpharm.2010.09.035.

Sharma, R., Joshi, V.K., Rana, J.C., 2011. Nutritional composition and processed products of Quince (Cydonia oblonga Mill). Indian J. Nat. Prod. Res. 2, 354-357.

Shinomiya, F., Hamauzu, Y., Kawahara, T., 2009. Anti-allergic effect of a hot-water extract of quince (Cydonia oblonga). Biosci. Biotechnol. Biochem. 73, 1773-1778. Available at: https://doi.org/10.1271/bbb.90130.

Silva, B. M., Andrade, P.B., Mendes, G. C., Seabra, R.M., Ferreira, M.A., 2002a. Phenolic profile of quince fruit (Cydonia oblonga Miller) (Pulp and Peel). J. Agric. Food Chem. 50, 4615-4618. Available at: https://doi.org/10.1021/jf0203139.

Silva, B.M., Andrade, P.B., Valentao, P., Ferreres, F., Seabra, R.M., Ferreira, M.A., 2004a. Quince (Cydonia oblonga). Miller) fruit (pulp, peel, and seed) and jam: antioxidant activity. J. Agric. Food Chem. 52, 4705-4712. Available at: https://doi.org/10.1021/jf040057v.

Silva, B.M., Andrade, P.B., Goncalves, A.C., Seabra, R.M., Oliveria, M.B., Ferreira, M.A., 2004b. Influence of jam processing upon the contents of phenolics, organic acids and free amino acids in quince fruit (Cydonia oblonga Miller). Eur. Food Res. Technol. 218, 385-389. Available at: https://doi.org/10.1007/s00217-003-0845-6.

Silva, B.M., Casal, S., Andrade, P.B., Seabra, M.R., Oliveira, M.B.P.P., Ferreira, M.A., 2004c. Free amino acid composition of Quince (Cydonia oblonga Miller) fruit (pulp and peel) and jam. J. Agric. Food Chem. 52, 1201-1206. Available at: https://doi.org/10.1021/jf030564x.

Silva. B.M., Andrade, P.B., Ferreres, F., Seabra, M.R., Oliveira, M.B.P.P., Margarida, A.F., 2005. Composition 
of Quince (Cydonia oblonga Miller) seeds: phenolics, organic acids and free amino acids. Nat. Prod. Res. 19, 275-281. Available at: http://dx.doi.org/10.1080/14786410410001714678.

Slpponen, P., Kekki, M., Haapakoski, J., Ihamaki, T., Siurala, M., 1985. Gastric cancer risk in chronic atrophic gastritis: statistical calculations of cross-sectional data. Int. J. Cancer 35, 173-177.

Smith, F., Montgomery, R., 1959. The Chemistry of Plant Gums and Mucilages. New York, NY: Reinhold Pub. Co.

Stenstrom, B., Mendis, A., Marshall, B., 2008. Helicobacter pylori-the latest in diagnosis treatment. Aus. Fam. Phys. 37, 608-612.

Szychowski, P.J., Munera-Picazo, S., Szumny, A., CarbonellBarrachina, A.A., Hernandez, F., 2014. Quality parameters, bio-compounds, antioxidant activity and sensory attributes of Spanish quinces (Cydonia oblonga Miller). Sci. Horti. 165, 163-170. Available at: https://doi.org/10.1016/j.scienta.2013.11.028.

Tabata, M., Honda, G., Sezik, E., Yesilada, E., 1993. A Report on Traditional Medicine and Medicinal Plants in Turkey (1990, 1991). Japan: Kyoto University Press.

Torkelson, A.R., 1995. The Cross Name Index to Medicinal Plants. London: CRC Press.

Trovato, A., Taviano, M.F., Pergolizzi, S., Campolo, L., De Pasquale, R., Miceli, N., 2010. Citrus bergamia risso and Poiteau juice protects against renal injury of diet-induced hypercholesterolemia in rats. Phytother. Res. 24, 514-519. Available at: https://doi.org/10.1002/ptr.2971.

Tuzlaci, E., Tolon, E., 2000. Turkish folk medicinal plants, part III: sile (Istanbul). Fitoterapia 71, 673-685.
Usmanghani, K., Saeed, A., Alam, M.T., 1997. Indusyunic Medicine. Karachi: University of Karachi Press.

Vaez, H., Hamidi, S., Arami, S., 2014. Potential of Cydonia oblonga leaves in cardiovascular disease. Hypothesis 12, 1-10. Available at: https://doi.org/10.5779/hypothesis.v12i1.356.

Wang, X., Jia, W., Zhao, A., 2006. Anti-influenza agents from plants and traditional Chinese medicine. Phytother. Res. 20, 335-341. Available at: https://doi.org/10.1002/ptr.1892.

Winter, C.A., Risley, E.A., Nuss, G.W., 1962. Carrageenin induced edema in hind paw of the rat as an assay for antiinflammatory drugs. Exp. Biol. Med. 111, 544-547. Available at: https://doi.org/10.3181\%2F00379727-11127849.

Xavier, R.J., Podolsky, D.K., 2007. Unravelling the pathogenesis of inflammatory bowel disease. Nature 448, 427-434. Available at: https://doi.org/10.1038/nature06005.

Yildirim, A., Oktay, M., Bilaloglu, V., 2001. The antioxidant activity of the leaves of Cydonia vulgaris. Turk. J. Med. Sci. 31, 23-27. Available at: https://doi.org/10.3389/fphar.2016.00163.

Zohalinezhad, M.E., Imanieh, M.H., Samani, S.M., Mohagheghzadeh, A., Dehghani, S.M., Haghighat, M., Salehi, A., Faridi, P., Akbarzadeh, A.R., 2015. Effects of Quince syrup on clinical symptoms of children with symptomatic gastroesophageal reflux disease: a doubleblind randomized controlled clinical trial.Compl. Ther. Clin. Pract. 21, 268-276. Available at: https://doi.org/10.1016/j.ctcp.2015.09.005.

\title{
Етнофармаколошки и токсиколошки преглед на Cydonia oblonga $\mathrm{M}$.
}

\author{
Катерина Цветковска, Билјана Бауер* \\ Фармачевтски факултет, Универзитет „Св. Кирил и Методи", Мајка Тереза 47, \\ 1000 Скопје, Република Македонија
}

\begin{abstract}
Клучни зборови: Cydonia oblonga, фитомедицина, фармаколошки атрибути, употреба во народната медицина, дуња
\end{abstract}

Cydonia oblonga M. е медицинска билка од фамилијата Rosaceae, која се користи за спречување или третирање на болести, како рак, дијабетес, хепатитис, чир, респираторни и уринарни инфекции итн. Cydonia oblonoga, позната како дуња е богата со секундарни метаболити како што се феноли, стероиди, флавоноиди, терпени, танини, органски киселини и гликозиди. Покажува широк спектар на фармаколошко дејство како антиоксидативно, антибактериско, антифунгално, антиинфламаторно, хепатопротективно, кардиоваскуларно, антидепресивно, хиполипидемично, диуретично дејство итн. Полисахаридниот слуз, глукороноксилан кој се наоѓa во семињата на дуњата, се користи во дерматологијата, за изработка на фластери за рани.

Целта на овој труд е фокус на детални истражувања на вредноста на фитохемикалиите, како фармаколошки атрибути на фитомедицинските билки. 